\title{
the serpent column: the persistent meanings of a pagan relic in christian and islamic constantinople ${ }^{1}$ rolf strootman
}




\begin{abstract}
In the heart of Istanbul, on the site of the former hippodrome, stand the remains of the Serpent Column, one of the most ancient and most enigmatic monuments in the city: a three-headed snake made of bronze to which various sacral and magical properties have been attributed in the past by pagans, Christians, Muslims, and Jews. Originally set up as a votive offering in Greece's central sacred site, Delphi, the column commemorated the Greek triumph in the Second Graeco-Persian War (480-479 BCE). This powerful icon of victory, couched in pagan principles of cosmology, was brought to Constantinople in the fourth century CE to become an emblem of the universal rule of the Christian Roman emperor. In late Byzantine and Ottoman times, the Serpent Column was seen as an apotropaic talisman safeguarding Constantinople from poisonous snakes. In this paper it is argued that the column retained its status as a powerful sacred object for so many centuries because in Constantinople it came to be associated with the Brazen Serpent lifted up in the desert by Moses (Numbers 21:4-9), which in turn was believed to prefigure the crucifixion and resurrection of Christ (John 3:14-15).
\end{abstract}

Keywords: Ottoman Empire, Istanbul, Delphi, Serpent Column, Jerusalem, Moses

Rolf Strootman is Associate Professor of Middle East History at the University of Utrecht. His research focuses on imperialism, monarchical ideology, and cultural encounters in the Near East, Iran and Central Asia, particularly in the era of Seleucid rule. He is the author of Court and Elites in the Hellenistic Empires: The Near East after the Achaemenids, 330-30 BCE (2014) and numerous articles on aspects of empire in the Hellenistic Near East.
Material Religion volume 10, issue 4, pp. 432-451 DOI: 10.2752/175183414X14176054221328

(C) Bloomsbury Publishing Plc 2014 
In The Decline and Fall of the Roman Empire, Edward Gibbon wrote that "the guardians of the most holy relics would rejoice if they were able to produce such a chain of evidence as may be alleged" for the Serpent Column (1909-14: II.152). As a later enthusiast added, "Perhaps nothing in the world has such a history" (Hutton 1909: 324).

The Serpent Column, one of the oldest and most remarkable artifacts in present-day Istanbul, indeed has a long history. This history, from its creation in Delphi in the fifth century BCE, through its placement in the hippodrome of Constantinople some 750 years later, until its heads broke off on October 20, 1700, has been recorded by Greek and Roman historians, a variety of Ottoman witnesses, and European travelers in the early modern period. Moreover, the column has a fascinating archaeological record. While remains of the inscribed marble base of the bronze statue are still to be found in situ in Delphi, far away in Istanbul almost 5.5 meters of the bronze shaft are preserved on the site of the former hippodrome, ${ }^{2}$ which is still known today as At Meydanı, Horses Square (Figure 1).

In the course of its long history, the Serpent Column accumulated a varied set of associations, meanings, and functions. This originally pagan monument was appropriated by Christians and Muslims, and perhaps also by Jews, as we will see below. The Serpent Column began its existence as a votive offering with cosmological overtones. In later centuries, it became a symbol of Constantinople's status as imperial capital, a fountain, a healing relic, and a talisman protecting the City of Wonders against venomous creatures.

\section{FIG 1}

Photograph of the remains of the Serpent Column in nineteenthcentury Constantinople. Photograph by an anonymous photographer, ca. 1860-90, Library of Congress (LC-USZ62-106170).

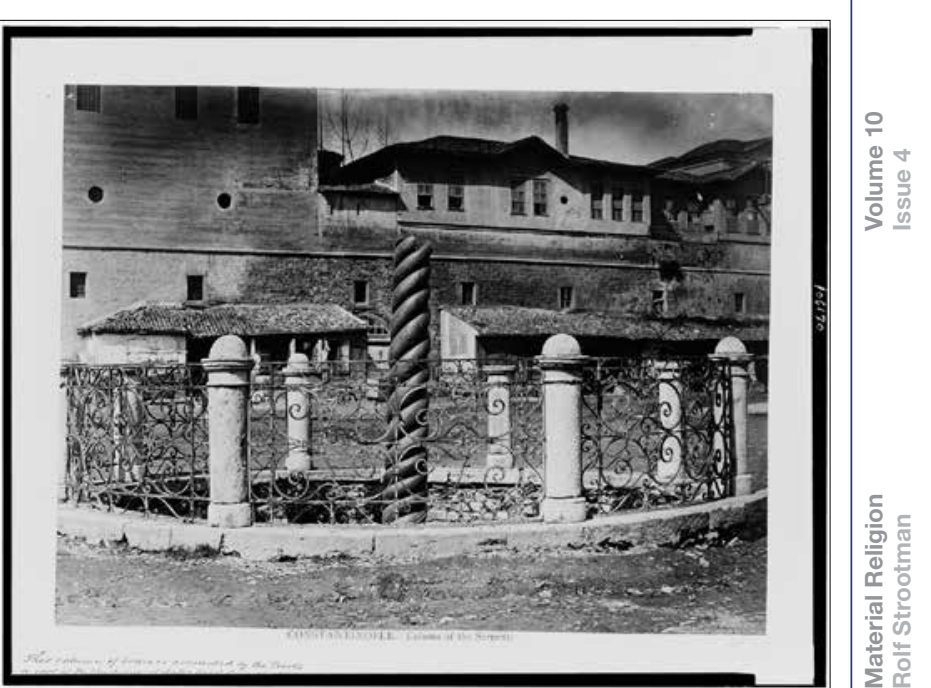


The focus of this paper is the column's healing and apotropaic powers, with which it was first particularly credited in the late Byzantine and early Ottoman periods. Because the earliest evidence attesting these powers dates to the early 1400s, modern scholars often assume that attribution of talismanic quality to the column was likewise of a relatively late date and that its original pagan meanings had been lost by that time. It is my contention that neither of these assumptions is valid. I argue instead that the monument's original political and cosmological associations (see below) remained very much part of its cultural biography, while it also acquired protective power in the course of the medieval period. Moreover, I hope to show how these two facets of the monument were interdependent and mutually reinforcing. Before turning to consider the Serpent Column as a talisman in Christian and Islamic times, we must first look at its original role as a pagan votive offering to the chthonic deity Apollo Delphinios and its early history as an emblem of imperial power in late Roman Constantinople.

\section{From Delphi to Constantinople}

Although the precise circumstances of its production are unknown, the Serpent Column was created after the Battle of Plataia (479 BCE) at which a coalition of Greek poleis defeated an Achaemenid expeditionary force, thereby ending the Second Graeco-Persian War (Laroche 1989). The monument was set up as a votive offering to Apollo at Delphi, the pan-Hellenic shrine that Greeks believed was the geographic heart of the world. Its creation and early history is relatively well attested in ancient Greek writings. ${ }^{3}$

From ancient sources and archaeology as well as from pictorial representations in early modern European travel books and Ottoman illuminated manuscripts, we know that the column originally had three heads. According to Herodotus, our oldest literary source for the column, rather than three intertwined snakes, the monument apparently represented a single three-headed serpent on a coiled body rising up from the chasms beneath Delphi, looking watchfully in the direction of the three barbaric continents, Asia, Europe, and Libya. ${ }^{4}$ A miracle of craftsmanship, in a deliberately archaic style, these three snake heads carried on top of them a gold tripod (an object sacred to Apollo), which was cast from the spoils of Plataia. ${ }^{5}$

From its prominent place near the main temple of Apollo, the Serpent Column was brought to Constantinople, probably by Constantine the Great himself, somewhere between 324 and 337 cE. The gold tripod had by that time already been lost. The column was placed in the hippodrome presumably directly at its 
arrival in the "New Rome" (Madden 1992: 112-16; cf. Stichel 1997: 320-2). It was given a conspicuous, central place among the various classical and Hellenistic bronzes adorning the hippodrome's spina (Bassett 2004: 58-71). It stood more or less opposite the kathisma, the imperial loge from which the emperor presented himself to the populace while watching processions and chariot races. The two obelisks that were later placed on the spina were located at equal distances on either side of the Serpent Column. Thomas Madden holds that Constantine (who was "both a good Christian and a good pagan") gave the Serpent Column this central place to underscore his affinity with the solar god, Sol Invictus, the imperial deity par excellence whom the Romans identified with Apollo (1992: 116). Arguing against Madden's view, Stichel (1997: 319) contends that Constantine was primarily interested in the column's reputation as a victory monument, which he used to bolster his own anti-Persian policy. But these two views are not mutually exclusive. On the contrary, both solar Apollo and the Graeco-Persian Wars were among the ideological constituents of a broader reason for the Serpent Column to be placed in the center of the new capital of the Roman Empire, as we will see below.

Snakes had long been associated with the cult at Delphi. It was here that Apollo had defeated the primordial serpent (drakōn) Python in an encounter that was seen as a struggle of order against chaos (Fontenrose 1959: 217-73; on the myth see now also Ogden 2013: 40-7). The Greek victory in the Second Graeco-Persian War (480-479 BCE) was likewise construed as a triumph of order over chaos, of civilization over barbarity; the Greeks' principal victory monument was erected in Delphi not only because it was an important pan-Hellenic sanctuary but also because of its cosmological significance. Delphi was the location of the Omphalos, the sacred stone that marked the center of the earth, under which Apollo had incarcerated Python. Connected with the divine order of the world, Delphi and Apollo figured prominently in Greek political propaganda directed against "barbaric" enemies such as Persians or Celts (Strootman 2005). Like most premodern imperial states, the Romano-Byzantine Empire propagated a vigorous universalistic ideology, which identified the empire with the civilized oikoumene (inhabited world), and eventually with Christendom. Once moved to Constantinople, the column served as a crucial element among the various symbols and monuments by which the city's status as imperial capital, and hence as center of the earth, was constructed (Strootman 2011; cf. Stephenson 2012). The hippodrome in particular was transformed by means of imperial rituals and symbols into a model of 
the universal cosmic order (Lyle 1984). Flanked by Hagia Sophia and the imperial palace, the hippodrome was the ritual and symbolic heart of Constantinople, the place where emperor and people met, and the Serpent Column was the center of the hippodrome.

Archaeological evidence, supported by the accounts of some fifteenth-century visitors, shows that sometime during the Byzantine centuries the column was converted into a fountain (Frick 1860: 550-1; Newton 1865: 27-8; cf. Stichel 1997: 322-6, and Stephenson in press). It presumably still functioned as such when the city fell to the Fourth Crusade in 1204. It is surely remarkable that the conquerors, who melted down or sold all other bronzes in the hippodrome, left only the Serpent Column untouched. Thomas Madden (1992: 120-3) speculates that if the water devices were still functional after 1204, the Serpent Fountain could have been quite useful to refresh mounted knights during tournaments. While jousting contests indeed took place in the hippodrome under the Frankish occupation, one may wonder if this alone suffices to account for the Crusader's remarkable "respect" for the Column. ${ }^{6}$ However this may be, it seems that when all monuments on the spina had disappeared except for the two obelisks and the Serpent Column, the latter began to attract attention. It became a kind of general indicator of the At Meydanı, the square that was the main showground for imperial festivities and processions in the Ottoman capital from ca. 1500 to 1700 (Figure 2). The survival in the city's central square of this bronze sculpture provoked strong reactions from residents and visitors alike, who attached new meanings to it.

It is, indeed, only after the Byzantine reconquest of Constantinople (1261) that we first hear about the column as a talisman protecting the city against poisonous snakes, as would later be noted by both Ottoman historians and European visitors. According to some accounts, the column even possessed the ability to cure snake bites. Thus the Serpent Column developed from an object with symbolic power into an object possessing agency.

Sometime before 1512, one of the heads lost its lower jaw (Ménage 1964: 170-1), and some of the snakes that had been chased out of town by the power of the Serpent Column allegedly returned (but only harmless ones). Finally, all three heads broke off on the evening of October 20,1700 - seemingly as the result of old age rather than deliberate vandalism (Ménage 1964: 173). The heads may have been ritually buried, or stored by the Ottoman authorities. One was retrieved in the early decades of the nineteenth century, presumably from an excavation site 


\section{FIG 2}

A snake charmer performing on At Meydanı. Miniature from the Surnâme-i Hümayûn ("Book of Festivities"), 1582.

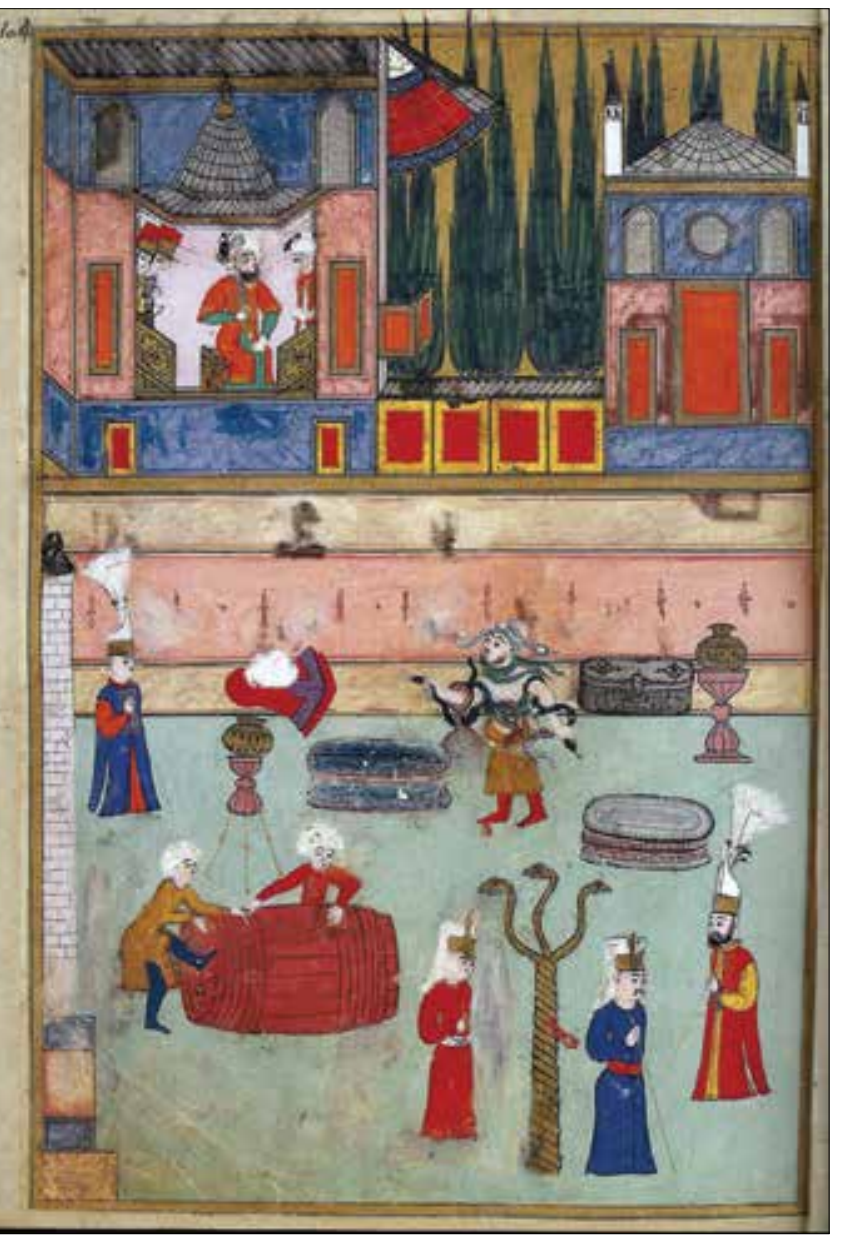

adjacent to Hagia Sophia. ${ }^{7}$ In the eyes of foreign visitors, the column had lost its attraction as a magical relic - only to gain new significance as an object of scholarly interest. Dangerous snakes never returned to Istanbul.

The earliest testimonies noting the column's apotropaic and healing qualities date to shortly before the Ottoman conquest in 1453. As noted above, some scholars have assumed that the development of the column's talismanic significance was of a relatively late date and that by that time its original significance had been lost. ${ }^{8}$ But although the association with Delphi and the Persian Wars may have become less prominent in the folklore surrounding the Serpent Column - most, though not all, European visitors describing the column in Constantinople between 1400 and 1700 fail to note the connection - the monument's original cosmological and political connotations were not forgotten. In addition to this, the monument developed the protective agency discussed above. In the last section of this paper, the Serpent Column's enduring cosmological, 
and perhaps even eschatological, significance will be further explored. But first we will have a better look at the monument's apotropaic powers. The principal sources for this are the accounts of travelers that appeared from the fourteenth century onward; in these accounts a variety of folk legends and popular beliefs have been recorded. ${ }^{9}$

\section{From the Byzantines to the Ottomans}

Russian visitors to Constantinople were the first to note the Serpent Column's alleged supernatural powers, in particular its healing capability. Their testimonies have been collected and translated by Majeska (1984). Around 1390, an anonymous Russian traveler was told that the Serpent Column turned three times each year. About the same time, a certain Ignatius of Smolensk heard that the column was filled with snake venom. Another Russian visitor, Alexander the Clerk, recorded around 1395 that the poison was put inside the column by Leo VI the Wise, who was Byzantine emperor from 886 to 912 . Finally, Zosima the Deacon, who was in Constantinople around 1425, says that on the square that once was the hippodrome "stands a column of brass ... with three asp heads. Serpent venom is sealed in them, and if anyone is stung by a snake inside the city and he touches this, he is cured" (Majeska 1984: 184). During his stay in Constantinople in 1403, Ruy Gonzales de Clavijo, a Spanish ambassador to Temür-i Lenk (Tamerlane), noted an additional function: the column was set up to terminate "a plague of serpents and other noisome reptiles who killed many people by their venom," so that "forthwith and ever after in Constantinople no serpent could harm anyone" (Gonzales de Clavijo 1928: 71).

After the Ottoman conquest of Constantinople (1453), the accounts shift their emphasis from viewing the column as an object offering a cure from snake bites to seeing it as a talisman protecting the city against venomous snakes, often adducing fanciful stories of the column's creation by a legendary ruler in response to a plague of snakes. For instance, the late sixteenth-century Ottoman historian Ahmad ibn Yūsuf al-Qaramānī (d. 1610), reported that

serpents and snakes appeared in the city and decimated men and cattle alike. Those who survived fled, and it remained empty for a while. Then, to drive these calamities away, [one emperor] fabricated a talisman, possibly the bronze one now presently shaped like three serpents. (el-Cheikh 2004: 221)

An earlier Ottoman historian, Kemāl Paşazāde, around 1510 attributed the establishment of the column to Constantine the Great, who "by making and designing that 
talisman stopped up the source of the mischief of snakes, whose poison is fatal to life. The snakes departed so that none was left there and those that remained became harmless" (Ménage 1964: 171). Several writers, moreover, record traditions about the missing lower jaw of one of the serpent heads. Mehmet II, Selim II, Süleyman II, and Murat IV have all been accused of striking off the jaw to show their strength. These stories are likely apocryphal. What is of significance, however, is the fact that in several accounts the loss of the jaw leads to the instant return of some, relatively harmless, snakes, as if a small breach had been created in the city's anti-serpentine defenses.

In recent years, an important new source has come to light that significantly enriches our understanding of the history of the column. A manuscript found in the library of the University of Amsterdam and now published by Joris Oddens (2009) contains an account of the travels of Gerard Hinlopen, a young denizen of Hoorn who went on a grand tour to Constantinople in 1670. Hinlopen writes extensively about the Serpent Column. Among other things, he records the usual legend about the column's erection as protection against poisonous snakes by a past ruler (this time Constantine XI, the last Byzantine emperor). However, basing his opinions on those of the erudite Pierre Gilles d'Alby (1490-1555) in his De topographia Constantinopoleos, Hinlopen gives more credence to the identification of the column with the victory monument erected in Delphi in commemoration of the Greek victory at Plataia, which he knew was brought to Constantinople by Constantine the Great. ${ }^{10}$ He then goes on to record a story he had been told about a more recent war with Persia. According to this story, the lower jaw of one of the serpent heads was struck off by accident by the Sultan Murat IV while practicing with a spear. This turned out to be somehow an omen connected with an upcoming campaign against the Safavids. This campaign culminated in the destruction of the Persian army and the recapture of Baghdad by the Ottomans in 1638. After the sultan's return, his mother, the powerful Kösem Sultan, dedicated a "church" on the site where her son's spear had come down (Oddens 2009: 163-4).

It appears that the association of the Serpent Column with Delphi and the Graeco-Persian Wars was not completely lost, as local folklore could still connect the monument with a recent victory over a Persian foe. ${ }^{11}$ Instead of acquiring a new meaning in a new historical context, the Serpent Column apparently had the ability to accumulate meanings.

Of relevance in this context is the testimony of another Dutch traveler, Cornelis de Bruijn, a professional artist who 
journeyed extensively through the Near East in the 1670s and later also through Russia and Iran. He published illustrated accounts of both travels. In the first of these, Travels through the Most Famous Parts of Asia Minor, the former hippodrome and its Serpent Column are described:

According to a common superstition this column was made by a talisman or by certain charms to protect against snakes ... Others believe that these three snakes symbolically signify the three continents (as the fourth was then not yet known) and that they pre-figure the re-union of the eastern and the western empires whose power now together encompasses the entire known world. ${ }^{12}$

De Bruijn was one of the last European travelers to see the Serpent Column before its three heads fell off and disappeared in 1700. He based his description in part on reports by earlier travel writers (which accounts for his misunderstanding of the word "talisman"), in particular the work of Jean Du Mont, who had visited Constantinople in 1690 and later wrote that the "three hissing heads ... threaten the three parts of the world, as it was then divided" (Grélois 2010: 234). The three serpent heads are rather frequently connected with the three continents in the travel accounts-evidence that the column's cosmological connotation as a marker of the geographical heart of the world was still alive by the seventeenth century. ${ }^{13}$

The most remarkable legend, recorded by both De Bruijn and Du Mont, is the eschatological expectation of the merging of Christendom and Islam, and the subsequent creation of a single unified world empire. De Bruijn and/or Du Mont may have heard about this prophecy from a Christian dragoman. In Christian eschatology, prior to the return of Christ and the Day of Judgment the Dragon (drakōn), the "old serpent" of Revelation 20:2 (i.e., Satan), will create a single empire encompassing all the peoples and nations of the earth (Revelation 13:1-8, cf. 16:13-14). ${ }^{14}$ Revelation 13 represents Rome as an atrocious beast rising from the abyss covered by the sea. In the early modern period, this beastly empire could easily be associated by Christians with the Ottoman Empire, which at the time was still the greatest power in Europe and beyond. It would seem that, at least for the local sources informing Du Mont and De Bruijn, the Serpent Column was still a portent prefiguring the Second Coming.

\section{The Serpent Column and the Brazen Serpent}

The belief that venomous snakes could be expelled, and serpent-like demons exorcized, by means of their own mirror image, was widespread in the Byzantine world, 
as was the principle of similia curantur, that is, the use of a representation of (the demon causing) a disease to heal it (Spier 1993; Kuehn 2011). This explains why the Serpent Column in the hippodrome could be viewed by the Byzantines as simultaneously a "repository of evil" (Stephenson 2010: 75) and a talisman protecting the city against evil.

The Serpent Column's healing and protective powers, as well as the apparently widespread belief that the column was first created to end a plague of venomous creatures, are reminiscent of the biblical story of the socalled Brazen Serpent, a bronze image of a serpent set up by Moses in the desert to cope with a plague of snakes. As recounted in the book of Numbers, when the Israelites complained against God and against Moses for having brought them into the waterless desert, they were instantly punished for their lack of faith:

And Yahweh sent fiery serpents among the people, and they bit the people; and much people of Israel died. And the people came to Moses, and said, We have sinned, because we have spoken against Yahweh, and against thee; pray unto Yahweh, that he take away the serpents from us. And Moses prayed for the people. And Yahweh said to Moses, Make thee a fiery serpent, and set it upon a standard: and it shall come to pass, that every one that is bitten, when he sees it, shall live. And Moses made a serpent of bronze, and set it upon the standard: and it came to pass, that if a serpent had bitten any man, when he looked unto the serpent of bronze, he lived. (Numbers 21:6-9) ${ }^{15}$

A connection of typology between the Brazen Serpent and the later belief in the apotropaic powers of the Serpent Column can safely be assumed. But is there also an ideological link? The Greek Old Testament (Septuaginta) may have been known in its entirety only to scholars; but Moses figured prominently in all variants of the Prophetologion, a Greek-language lectionary containing selected Old Testament texts for use in the Byzantine liturgy. It was through recitations from lectionaries like the Prophetologion and the Gospel Lectionary that the wider populace knew its Holy Scripture (Zuntz 1956; Miller 2010).

Moreover, despite its seemingly idolatrous overtones, the story of the Brazen Serpent takes pride of place in Christian theology because it came to be seen as a prefiguration of the Crucifixion, and hence of the Resurrection. The correlation is based on a saying of Jesus in the Gospel of John: "As Moses lifted up the serpent in the wilderness, even so must the son of man be lifted up; that whoever believes in him should not perish 
but have eternal life" (John 3:14-15). Thus, Christian theologians like the late fourth-century archbishop John Chrysostom were able to associate the Brazen Serpent in the book of Numbers with the Cross:

In the former, the uplifted serpent healed the bites of the serpents; in the latter, the crucified Jesus healed the wounds inflicted by the spiritual dragon. In the former, there was the uplifted brass fashioned in the likeness of the serpent; in the latter, the Lord's body formed by the Spirit. ${ }^{16}$

According to the Byzantine Gospel lectionaries, reference to the Brazen Serpent in John 3 was recited each year on the first Thursday after the Orthodox world's principal religious festival, Easter (Jordan 2009: 335), and this practice continued through the Ottoman centuries until the present day. It is easy to see that Byzantine laypersons must have known this story well.

Fortunately, there also is direct evidence that in the Middle Ages the Serpent Column and the Brazen Serpent were thought to be somehow connected. The evidence includes a small enamel depicting the baptism of Christ on the so-called Pala d'Oro, a sumptuous twelfth-century altarpiece now in the basilica of San Marco in Venice. The enamel, which was produced in a workshop in Constantinople, ${ }^{17}$ features a remarkable image of a column with a cross on top (Figure 3). Art historians generally describe it simply as "a column"

\section{FIG 3}

Baptism of Christ. Byzantine enamel in the Pala d'Oro in the San Marco, Venice.

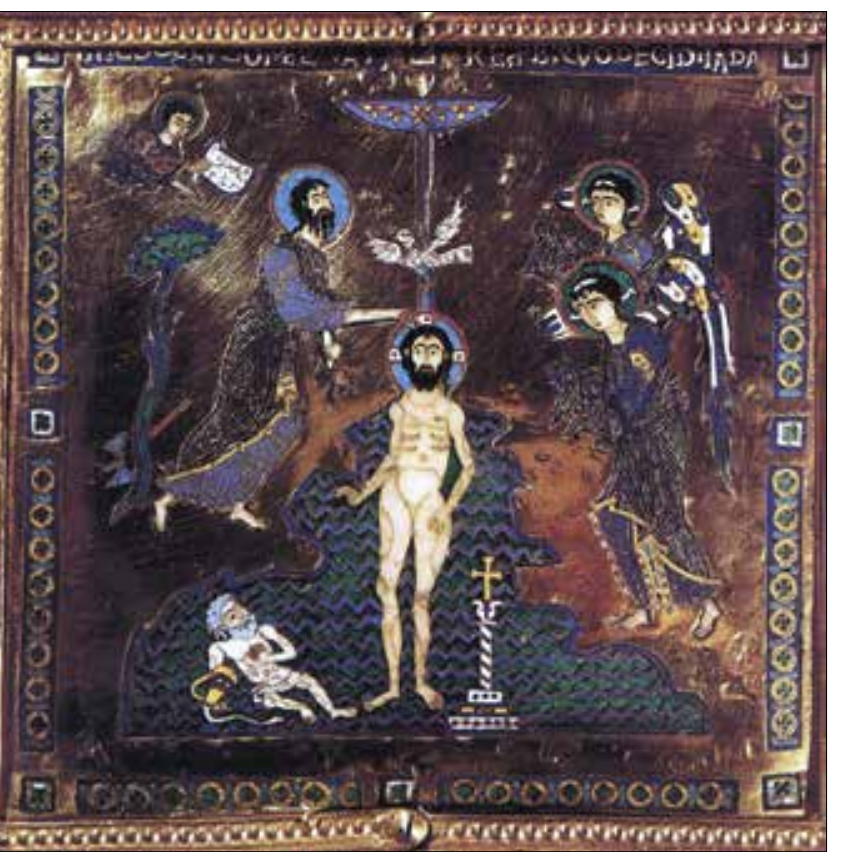


without attempting to explain its prominent place in the center of the scene, next to the figure of Jesus (LuigiPomorišac 1966: 31; Hahnloser and Polacco 1994: 28-9). But with its coiled shaft crowned by what may well be two snake heads extending to the right and to the left, this column looks conspicuously like the Delphic monument in Constantinople. It thus likely represents the Brazen Serpent of John 3, modeled after the Serpent Column. This interpretation is confirmed by two representations of the Serpent Column from medieval Cyprus (Stichel 1997: 324-5 with figures 52.1 and 52.2). The first of these is a fresco in a church in the village of Moutoullas, dated to 1280, showing the Serpent Column next to the Theotokos (the Virgin Mary holding the infant Jesus). The second is the Larnaka Tympanum, a thirteenth-century marble relief from a Cypriote church that is now in the Victoria and Albert Museum in London. ${ }^{18}$ The tympanum consists of a central depiction of the ascension of Christ bordered by smaller reliefs depicting the Annunciation, the Baptism, and the Crucifixion. The Serpent Column is clearly recognizable in the center of the Annunciation scene. It is placed conspicuously between the figures of the archangel Gabriel and Mary. Again, the most likely explanation for the appearance of a column shaped like the Serpent Column in a pivotal Christian scene is that this familiar image was used to represent the Brazen Serpent, foreshadowing the Cross and the Resurrection.

Because the eternal life promised in John 3:15 would be bestowed only at the Last Judgment, we have returned to De Bruijn's observations regarding the Serpent Column as a portent of the eschatological unification of the human world prior to the Second Coming. According to Sara Kuehn, the serpent lifted up by Moses in the desert became through its association with Christ the counterpart of the satanic serpent from Genesis (Kuehn 2011: 68; cf. Kessler 2009), and consequently of the satanic serpent in Revelation as well. ${ }^{19}$ Moreover, Stephenson (2010) has explored the possible association of the Serpent Column with the Day of Judgment, drawing attention to the appearance of three-headed serpents in Byzantine Last Judgment scenes. ${ }^{20}$

\section{The Brazen Serpent in Jewish Imagination}

Let us take this point one step further. It is worth entertaining the possibility that the Brazen Serpent and the Serpent Column were in fact regarded as one and the same relic by Jews in Byzantium and the Levant, who responded to their own political situation with a combination of historicizing legends and eschatological expectations. 
According to one tradition, recorded in 2 Kings 18, King Hezekiah of Judah (715-687 BCE) purged Israelite religion of idolatrous objects and places of worship in an attempt to centralize and control the cult. He is said to have removed from the sanctuary of Yahweh in Jerusalem the sacred asherah (perhaps an image of the deity Asherah) and to have smashed "the bronze snake Moses had made; they called it Nehushtan and until that day the people of Israel had been offering incense to it" (2 Kings 18:4). ${ }^{21}$ Snake cults were common in Judah during the first quarter of the first millennium BCE (Joines 1974), and the Nehushtan may have been the symbol of "a thirdlevel deity" who specialized in the healing of snakebites (Handy 1995: 41-2). In the days of emerging Yahwism, the presence of this object in the Temple was perhaps legitimized by identifying it as something Moses had made; in the view of some, it was not really an "idol" at all.

If the Brazen Serpent was indeed at one time kept in Jerusalem, it could have reached Constantinople, as all first-class relics eventually must. Constantinople was seen as the New Jerusalem from at least 500 CE (Guran 2006; Ousterhout 2010). It was the home of the True Cross and many more relics associated with the crucifixion and resurrection of Christ (Flusin 2000), including the staff of Moses. ${ }^{22}$ Particularly under the Macedonian Dynasty (867-1059), the emperors' Greek Orthodox subjects came to be seen as the biblical chosen people; they, and not the Jews, were "God's own people" and "the True Israel" (Magdalino and Nelson 2010: 20-4). Eusebios applied Moses imagery consistently to Constantine the Great in his Life of Constantine, written shortly after 337, and this example was followed by several later emperors (Rapp 1998; 2010). Old Testament models inspired the monarchical self-presentation of many, particularly Macedonian emperors, who were likened to David and especially Solomon, but also to Moses in his capacity as lawgiver (Magdalino and Nelson 2010: 24-6).

More research is needed. But if this hypothesis is correct, then a possible Jewish perspective on sacred relics comes into view, too. Until the tenth century, Jewish scholars engaged in debate with Christian theologians; in Byzantium the Old Testament was "more than a repository of devotional and doctrinal texts [it was] a contested cultural inheritance" (Magdalino and Nelson 2010: 6-7). Indeed, Jewish rabbis vigorously challenged the Christian appropriation of the Holy Land, of Israelite identity, and of Jewish relics. The imperial conceptualization of Constantinople as the New Jerusalem, and the emperor as a new Solomon, was countered in Jewish thought by the conceptualization of Jerusalem as the future 
Constantinople (Sivertsev 2011). This is seen, for instance, in an anonymous rabbinic manuscript from the sixteenth century (though based on older views) in which King Solomon is portrayed with all the trappings and powers of a Byzantine basileus, and biblical Jerusalem is shaped as a mirror image of the Byzantine capital. Most importantly, in this imagined Jerusalem, a hippodrome like the one in Constantinople provides the ritualized surroundings for the placement of the cosmic Throne of Solomon. ${ }^{23}$

The theme of the return of the Temple relics to Jerusalem played a crucial role in Jewish narratives about the future restoration of Israel (Boustan 2008 and 2011; Sivertsev 2011: 132). So when in Late Antiquity the myth arose that the Temple Vessels, which had been brought to Rome by Titus in $70 \mathrm{CE}$, had been translated to Constantinople by the Byzantine general Belisarius in $534,{ }^{24}$ Jewish rabbis needed to respond. Ra'anan Boustan (2008) has shown that since Late Antiquity the motif of the dislocation of the Temple Vessels had been incorporated into Jewish messianic discourse: acceptance of the notion that the most sacred relics of Israel were in the hands of the enemies of Israel was fitted into an eschatological scenario according to which the restoration of Israel would begin in the heart of the empire; and that the relics collected there were only awaiting their triumphant return to the Holy Land was similarly regarded: "The [Christian] Romans misrecognize their possession of these relics as physical confirmation of their divine election, [but] the very condition of dispersal serves as the precondition for the construction of restoration" (Boustan 2008: 366; also Weitzman 2005: 96-117). Could it be possible that the Brazen Serpent lifted up by Moses in the wilderness was thought to be among the Jewish relics in the possession of the Christian empire? Given the pivotal importance of the Brazen Serpent in Christian thought, and the central role of Moses in Jewish cultural memory, Christians and Jews cannot but have contemplated the present location of the relic. And where else could it be, but in Constantinople?

\section{notes and references}

1 This paper has benefited from discussions with Claudia Rapp and Ra'anan Boustan during my stay at UCLA in the Spring Semester of 2011; I am grateful to Dr Boustan for drawing my attention to the 
late antique rabbinic discourses on Jerusalem and Constantinople and for inviting me to the "Matter of Contention" conference at the University of Texas, Austin, in April 2012. The paper has furthermore greatly benefited from the many suggestions and critical remarks of Paul Stephenson, who kindly read and commented upon it, and by the peer-reviewers for Material Religion. After this paper was finished, my attention was drawn to a newly published paper by Francesca Dell'Acqua (2013), who also associates the Serpent Column in Constantinople with Moses' Brazen Serpent, but following a different line of argumentation; in his forthcoming monograph on the Serpent Column, Stephenson, too, will discuss the possible association with the Brazen Serpent as well as eschatological aspects.

2 To be precise, a shaft of hollow cast, 5.35 meters high, consisting of twenty-nine coils of the snake's erect body (Gauer 1968: 75-96). The lower coils are inscribed with a list of Greek poleis that partook in the Battle of Plataia (Syll. $\left.{ }^{3} 31\right)$. In 1855 Charles Newton excavated the lower part of the bronze column, but he left before it was clear there was an inscription. Frick and Dethier later removed the accretions with acid to reveal the inscription, thus adducing unambiguous evidence that the column in Constantinople was indeed the same as the Serpent Column of Delphi (Newton 1865: II 27-8; Frick 1859; cf. Casson et al. 1928: 25-6).

${ }^{3}$ The principal sources are (in chronological order): Herodotus 9.81; Thucydides 1.132: Plutarch Life of Themistokles 20-1; and Pausanias 10.13.4.

4 "Having brought all the loot together, they set apart a tithe for the god of Delphi. From this was made and dedicated that tripod which rests upon the bronze three-headed serpent ( $\tau \rho ı \alpha \rho \eta ́ v o v$

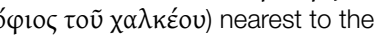
altar" (Histories IX 81.1; trans. A. D. Godley).

${ }^{5}$ For reconstructions of the column's appearance and method of construction, see most recently Steinhardt 1997; cf. i.a. Gauer 1968: 75-96; Ridgway 1977; Laroche 1989.

${ }^{6}$ As Stephenson (in press) points out, there were other fountains in the hippodrome that were destroyed; there furthermore is no evidence that the water came from the heads. Madden's hypothesis is accepted by Bardill 2010: 167.

${ }^{7}$ On the unearthing of the head, see Stichel 1997: 346-7.

${ }^{8}$ E.g., Madden 1992: 122 and 119-20, assuming that the column was not seen as a talisman until well after the city's conquest by the Crusaders (1204), and dating the loss of its original meaning as a victory monument to at least ca. 500.

${ }^{9}$ For an excellent overview of western European travelers' accounts of the hippodrome, see Grélois 2010, specifically the discussion of the Serpent Column and its magical powers at pp. 223-4 and 231-4.

10 "Others maintain that this snake with its three heads was only erected to bear the golden tripod of Delphos, as Pieter Gillius believes, although this was refuted at length by Pietro della Valla," After a long excursus on the Greek-Persian wars and the erection of the victory monument at Delphi, Hinlopen concludes that it was this column that "according to several historians had been brought here by the emperor Constantine" (Oddens 2009: 161; my translation).

${ }^{11}$ Cf. Stichel 1997: 318-19, showing that the connection between the Serpent Column and the Graeco-Persian Wars was still known at the time that Constantine the Great was emperor (307-37 $\mathrm{CE})$; the enduring Persian connection in Ottoman times is also noticed by Dell'Acqua (2013).

12 De Bruijn 1698: 49-50; translated from the Dutch by the author. De Bruijn evidently used the account of Jean Du Mont, who wrote several years earlier that some "maintained that this column was nothing short of an 
emblem of the union the western and eastern empires, spreading its power through the entire universe" (Grélois 2010: 234).

${ }^{13}$ The one head that missed its lower jaw is described as looking "in the direction of the Christians" by Hinlopen (Oddens 2009: 163), and "to the West" by Evliya Çelebi (Schmidt 2011: 212).

${ }^{14}$ Eschatological expectations had been connected with Constantinople by Christians already when the city fell to the Ottomans in 1453 and the Cretan philosopher George of Trebizond urged Sultan Mehmet II to restore the Roman Empire and establish Muslim rule over the entire world as a prerequisite for the imminent apocalypse (Lobovikova 2010). Medieval Islamic apocalyptic literature, too, presented the divinely foretold Muslim conquest of Constantinople as one of the last signs announcing the end of time (Cook 1996; el-Cheikh 2004: 60-71).

15 Translation of this and other Bible passages: American Standard Version (1901), with minor adjustments.

16 Translated by T. A. Goggin 1957-60, cited from Kuehn 2011 : 68.

17 The enamel is part of a series of enamels each measuring approximately $13 \times 13 \mathrm{~cm}$ that were only later incorporated in the Pala d'Oro. It is not known what the enamels originally were made for; they may have been commissioned by the Venetian doge Falieri in ca. 1105 (LuigiPomorišac 1966: 30) or by the Byzantine emperors Manuel I or Alexios I in the second half of the twelfth century (Bettini 1984: 60-6).

${ }^{18}$ Inv. No. A.2-1982, see Williamson 1996: 49. The exact provenance of the tympanum is unknown; its authenticity has been doubted by Hetherington 2000 , but is accepted by Stephenson (2010: 72) as well as by the museum, which dates it with some measure of uncertainty to ca. 1210-30, i.e, the period of Crusader rule in Cyprus. A good image of the tympanum is available at the museum's website (collections.vam.ac.uk).

19 James Charlesworth's recent book on ancient snake cults (2010) examines the (pagan) antecedents of the snake symbolism in John 3 , rightly stressing already in the title the ambiguous cultural comprehension of snakes in most Near Eastern civilizations as being simultaneously good and evil. For Byzantine apotropaic representations of serpents and dragons associated with the Cross see Kuehn 2011: 67-8.

${ }^{20}$ For the existence of real millenarian fears and expectations in the Byzantine Empire in the ninth and tenth centuries, see Magdalino 2003: 249-56. Berger (2010) briefly notes apocalyptic prophecies being attributed to the bronzes in the hippodrome, in particular the Skylla group that was destroyed by the Crusaders in 2014; cf. Mango 1963: 61 and 68.

${ }^{21}$ On the relation between the Brazen Serpent and the Nehushtan, see Joines 1974: 85-96.

${ }^{22}$ In a paper on the equation of Constantine and Moses in Eusebios, Rapp (1998, 693-4) draws attention to the fact that in patristic literature the staff of Moses was seen as a prefiguration of the cross, and that this relic was, therefore, carried in imperial processions together with Constantine's real cross.

${ }^{23}$ Text and translation in VillePatlagean 1962: 31-3; on the Throne of Solomon in rabbinic literature, see now Boustan 2013.

${ }^{24}$ Boustan 2008: 356-62. The fact that Scripture says that the Nehushtan was broken by Hezekiah and the Serpent Column stood intact in Constantinople is an inconsistency that does not seem to have posed a problem.

Bardill, Jonathan. 2010. The Monuments and Decoration of the Hippodrome in Constantinople. In Hippodrom/Atmeydanı I, ed. B. Pitarakis. Istanbul: Pera Müzesi, 149-84. 
Bassett, Sarah. 2004. The Urban Image of Late Antique Constantinople. Cambridge: Cambridge University Press.

Berger, Albrecht. 2010. The Hippodrome of Constantinople in Folklore and Legend. In Hippodrom/Atmeydanı I, ed. B. Pitarakis. Istanbul: Pera Müzesi, 194-205.

Bettini, Sergio. 1984. Venise, La Pala d'Oro et Constantinople. In: Le Trésor de Saint-Marc de Venise. Paris: Éditions de la Réunion des Musées Nationaux, 47-76.

Boustan, Ra'anan. 2008. The Spoils of the Jerusalem Temple at Rome and Constantinople: Jewish Counter-geography in a Christianizing Empire. In Antiquity in Antiquity: Jewish and Christian Pasts in the Greco-Roman World, ed. Gregg Gardner and Kevin Osterloh. Tübingen: Mohr Siebeck, 327-72.

Boustan, Ra'anan. 2011. The Dislocation of the Temple Vessels: Mobile Sanctity and Rabbinic Rhetorics of Space. In Tradition, Authority, Diaspora: Jewish Studies at the Crossroads of History and Anthropology, ed. Ra'anan Boustan, Oren Kosansky, and Marina Rustow. Philadelphia: University of Pennsylvania Press, 135-46.

Boustan, Ra'anan. 2013. Israelite Kingship, Christian Rome, and the Jewish Imperial Imagination: Midrashic Precursors to the Medieval "Throne of Solomon." In Jews, Christians, and the Roman Empire: The Poetics of Power in Late Antiquity, ed. Natalie Dohrmann and Annette Yoshiko Reed. Philadelphia: University of Pennsylvania Press, 167-82.

Casson, Stanley, et al. 1928. Preliminary Report Upon the Excavations Carried Out in the Hippodrome of Constantinople in 1927. Oxford: Oxford University Press.

Charlesworth, James. 2010. The

Good and Evil Serpent: How a Universal Symbol Became Christianized. New Haven, CT: Yale University Press.
Cook, David. 1996. Muslim Apocalyptic and Jihad. Jerusalem Studies in Arabic and Islam 20: 66-104.

De Bruijn, Cornelis. 1698. Reizen van Cornelis de Bruyn. Delft: Hendrik van Krooneveld.

Dell'Acqua Boyvadaoğlu, Francesca. 2013. Constantinople 1453: The Patriarch Gennadios, Mehmet the II and the Serpent Column in the Hippodrome. In Synergies in Visual Culture/ Bildkulturen im Dialog: Festschrift für Gerhard Wolf, ed. M. De Giorgi, A. Hoffmann, and N. Suthor. Munich: Wilhelm Fink Verlag.

El-Cheikh, Nadia Maria. 2004. Byzantium Viewed by the Arabs. Cambridge, MA: Harvard University Press.

Flusin, Bernard. 2000. Construire une nouvelle Jérusalem:

Constantinople et les reliques. In l'Orient dans l'histoire religieuse de l'Europe: l'invention des origines, ed. M. A. Amir-Moezzi and J. Scheid. Turnhout: Brepols, 51-70.

Fontenrose, Joseph. 1959. Python: A Study of Delphic Myth and its Origins. Berkeley: University of California Press.

Frick, Otto. 1859. Das plataeische Weihgeschenk zu Konstantinopel: Ein Beitrag zur Geschichte der Perserkriege. Leipzig: B. G. Teubner.

Frick, Otto. 1860. Das Plataeische Weihgeschenk zu Konstantinopel. Jahrbücher für Classische Philologie 3(4): 499-513.

Gauer, W. 1968. Weihgeschenken aus den Perserkriegen. Istanbul.

Gibbon, Edward. 1909-14. The Decline and Fall of the Roman Empire, ed. J. B. Bury. London: Methuen.

Gonzales de Clavijo, Ruy. 1928. Embassy to Tamerlane, 1403-1406, ed. and trans. Guy le Strange. London: Routledge.

Grélois, Jean-Pierre. 2010. Western Travelers' Perspectives on the Hippodrome/Atmeydanı: Realities and Legends (FifteenthSeventeenth Centuries). In Hippodrom/Atmeydanı I, ed. 
B. Pitarakis. Istanbul: Pera Müzesi, 213-41.

Guran, P. 2006. The Byzantine "New Jerusalem" at the Crossing of Sacred Space and Political Theology. In New Jerusalems: The Translation of Sacred Space in Christian Culture, ed. Alexei Lidov. Moscow: Indrik, 17-23.

Hahnloser, H. R., and Polacco, R. 1994. La Pala d'Oro. Venice: Canal \& Stamperia Editrice.

Handy, L. K. 1995. The

Appearance of Pantheon in Judah. In The Triumph of Elohim: From Yahwisms to Judaisms, ed. D. V. Edelman. Kampen: Kok, 27-44.

Hetherington, Paul. 2000. The "Larnaka Tympanum" and Its Origins: A Persisting Problem from 19th Century Cyprus. In Report of the Department of Antiquities, Cyprus. Nicosia: Department of Antiquities, 361-79.

Hutton, William. 1909. The Story of Constantinople. London: J. M. Dent \& Co.

Joines, Karen. 1974. Serpent Symbolism in the Old Testament: A Linguistic, Archaeological, and Literary Study. Haddonfield, NJ: Haddonfield House.

Jordan, Christopher. 2009. The Textual Tradition of the Gospel of John in Greek Gospel Lectionaries from the Middle Byzantine Period (8th-11th Century). PhD dissertation, University of Birmingham.

Kessler, Herbert L. 2009. Christ the Magic Dragon. Gesta 49: 119-34.

Kuehn, Sara. 2011. The Dragon in Medieval East Christian and Islamic Art. Leiden: Brill.

Laroche, Didier. 1989.

Nouvelles observations sur l'offrande de Platées. Bulletin de Correspondance Hellénique 113: 183-98.

Lobovikova, Ksenia I. 2010. George of Trebizond's Views on Islam and Their Eschatological Backgrounds. In Patrologia Pacifica: Selected Papers Presented to the Asia Pacific Early Christian Studies Society, ed. V. Baranov, K. Demura, and
B. Lourie. Piscataway, NJ: Gorgias Press, 346-65.

Luigi-Pomorišac, Jasminka. 1966. Les émaux Byzantines de la Pala d'Oro de l'Église de Saint-Marc à Venise. Zürich: Éditions P. G. Keller.

Lyle, Emily. 1984. The Circus as Cosmos. Latomus 43: 827-41.

Madden, Thomas. 1992. The Serpent Column of Delphi in Constantinople: Placement, Purposes, and Mutilations. Byzantine and Modern Greek Studies 16: 111-46.

Magdalino, Paul. 2003. The Year 1000 in Byzantium. In Byzantium in the Year 1000, ed. Paul Magdalino. Leiden: Brill, 233-70.

Magdalino, Paul, and Nelson, Robert. 2010. Introduction. In The Old Testament in Byzantium, ed. Paul Magdalino and Robert Nelson. Washington, DC: Dumbarton Oaks, 1-38.

Majeska, George. 1984. Russian Travelers to Constantinople in the Fourteenth and Fifteenth Centuries. Washington, DC: Dumbarton Oaks.

Mango, Cyril. 1963. Antique Statuary and the Byzantine Beholder. Dumbarton Oaks Papers 17: 53-75.

Ménage, V. 1964. The Serpent Column in Ottoman Sources. Anatolian Studies 14: 169-73.

Miller, James. 2010. The Prophetologion: The Old Testament of Byzantine Christianity. In The Old Testament in Byzantium, ed. Paul Magdalino and Robert Nelson. Washington, DC: Dumbarton Oaks, 55-76.

Newton, Charles Thomas. 1865. Travels and Discoveries in the Levant. London: Day \& Son.

Nutku, Özdemir. 2010. Festivities in Atmeydanı. In Hippodrom/ Atmeydanı II, ed. E. Işịn. Istanbul: Pera Müzesi, 71-95.

Oddens, Joris. 2009. Een vorstelijk voorland: Gerard Hinlopen op reis naar Istanbul (1670-1671). Zutphen: Walburg Pers.

Ogden, Daniel. 2013. Drakōn: Dragon Myth and Serpent Cult in the Greek and Roman Worlds. Oxford: Oxford University Press. 
Ousterhout, Robert. 2010. New Temples and New Solomons: The Rhetoric of Byzantine Architecture. In The Old Testament in Byzantium, ed. Paul Magdalino and Robert Nelson. Washington, DC:

Dumbarton Oaks, 223-54.

Rapp, Claudia. 1998. Imperial Ideology in the Making: Eusebius of Caesarea on Constantine as "Bishop." Journal of Theological Studies n.s. 49: 685-95.

Rapp, Claudia. 2010. Old Testament Models for Emperors in Early Byzantium. In The Old Testament in Byzantium, ed. Paul Magdalino and Robert Nelson. Washington, DC: Dumbarton Oaks, 175-98.

Ridgway, Brunilde. 1977. The Plataian Tripod and the Serpentine Column. American Journal of Archaeology 81(3): 374-9.

Schmidt, J. 2011. Byzantijns Istanbul door de ogen van zeventiende-eeuwse reizigers. In Constantinopel: Een mozaïek van de Byzantijnse metropool, ed. Diederik Burgersdijk and Willemijn Waal. Leuven: Peeters, 199-212.

Sivertsev, Alexei. 2011. Judaism and Imperial Ideology in Late Antiquity. Cambridge: Cambridge University Press.

Spier, Jeffrey. 1993. Medieval Byzantine Magical Amulets and their Tradition. Journal of the Warburg and Courtauld Institutes 56: 25-62.

Steinhardt, Matthias. 1997. Bemerkungen zu Rekonstruktion, Ikonographie und Inschrift des platäischen Weihgeschenkes. Bulletin de Correspondence Hellénique 121: 33-69.

Stephenson, Paul. 2010. Staring at Serpents in Tenth-Century Constantinople. Bysantinska sällskapet Bulletin 28: 58-81.

Stephenson, Paul. 2012. Constantijn en de monumentalisering van Constantinopel. In Constantijn de Grote: Traditie en verandering, ed. Olivier Hekster and Corjo Jansen. Nijmegen: Vantilt, 134-55.

Stephenson, Paul. In press. The Serpent Column Fountain. In The Fountains of Byzantion Constantinople - Istanbul, ed. Paul Stephenson and Ingela Nilsson. Cambridge: Cambridge University Press.

Stichel, Rudolf. 1997. Die "Schlangensäule" im Hippodrom von Istanbul. Zum spät- und nachantiken Schicksal des Delphischen Votivs der Schlacht von Plataiai. Istanbuler Mitteilungen 47: 315-48.

Strootman, Rolf. 2005. Kings against Celts: Deliverance from Barbarians as a Theme in Hellenistic Royal Propaganda. In The Manipulative Mode: Political Propaganda in Antiquity, ed. K. Enenkel and I. L. Pfeijffer. Leiden: Brill, 101-41.

Strootman, Rolf. 2011.

Hippodroom wordt Paardenplein.

De wederopstanding van Constantinopel na 1453. In Constantinopel. Een mozaïek van de Byzantijnse metropool, ed. Diederik Burgersdijk and Willemijn Waal. Leuven: Peeters, 183-98.

Ville-Patlagean, Evelyne. 1962 Une image de Salomon en basileus byzantin. Revue des Études Juives 121: 1-33.

Weitzman, Steven. 2005. Surviving Sacrilege: Cultural Persistence in Jewish Antiquity. Cambridge, MA: Harvard University Press.

Williamson, Paul. 1996. European Sculpture at the Victoria and Albert Museum. London: V\&A Publications.

Zuntz, Günther. 1956. Das byzantinische SeptuagintaLektionar ('Prophetologion'). Classica et Mediaevalia 17: 183-98. 